\title{
DESIGN AUDIT: VISUAL IDENTITY OF HET HUISJE CAFE
}

\author{
Gredi Gradana Sembada ${ }^{1}$, Chandra Renaldi ${ }^{2}$ \\ Universitas Telkom, Desain Komunikasi Visual \\ e-mail: 19radanagredi@yahoo.com, ${ }^{2}$ chandrarenaldi109@gmail.com
}

\begin{abstract}
The cafe business continues to experience significant developments, cafes being a favorite location to gather as part of the community's lifestyle. Currently there are more than ten thousand cafes in all corners of the country. In the 2013-2018 edition, the total revenue of the cafe sector is predicted to increase from USD 3.4 billion to USD 4.16 billion.The lifestyles of urban societies socializing in cafes are made a profit-making opportunity for business people by creating cafes with unique concepts. One of them is Het Huisje cafe. The cafe, which was established in early 2016, is located on Jl. Arif Rahman Hakim no. 9A, Pancoran Mas, Depok. the profit earned by Het Huisje cafe is static, in one month only a $10 \%$ increase in profit. Branding activities took the role of the case. The Het Huisje cafe logo that is not yet strongly illustrates the concept of its business. Visual Audit Results from pre-research Designs Audit, Het Huisje cafe logos do not meet the criteria of a good logo. The first phase of the study focused on visual audit on the logo. Methods of data collection using field observation instruments, interviews and questionnaires. Analysis using Design Audit matrix.The results of analysis in addition to being input for the design of promotional strategies are also used as input for the preparation of the design strategy process. The benefits of this research can be considered in making business decisions related to the field of design, so that the resulting design output is judged not only aesthetically, but also can be seen as a strategic step in achieving business goals
\end{abstract}

Keywords: Design Audit, Visual Identity, Logo, café. 


\section{PRELIMINARY}

The cafe business continues to experience significant developments, cafes being a favorite location to gather as part of the community's lifestyle. Currently there are more than ten thousand cafes in all corners of the country. In the 2013-2018 edition, the total revenue of the cafe sector is predicted to increase from USD 3.4 billion to USD 4.16 billion. The development of cafes in Indonesia especially in big cities such as Jakarta is growing rapidly. Socializing in the cafe is an urban lifestyle trend.

The lifestyles of urban societies socializing in cafes are made a profit-making opportunity for business people by creating cafes with unique concepts. Lifestyle like this increasingly lifted with the social media where urban people vying to show off their lifestyle by showing their hangout location, what they do, what they eat, and with whom they gather through social media

The development of cafe business in Depok city is growing rapidly. Many cafes offer diverse menus as well as the uniqueness of the concept that appeals to consumers. One of them is Het Huisje cafe. The cafe, which was established in early 2016, is located on Jl. Arif Rahman Hakim no. 9A, Pancoran Mas, Depok. The name Het Huisje is taken from Dutch which means small house. The concept offered by the Het Huisje cafe is a Dutch vintage impression from the 1920s, through the Mondrian style made into ornaments on the walls of the cafe. Mondrian style is taken from a Dutch painter Piet Mondrian. The typical Mondrian style uses primary colors such as red, yellow, and blue. In addition, in Mondrian's famous paintings use vertical and horizontal lines that are black in color.
According to interviews with the owner, the profit earned by Het Huisje cafe is static, in one month only a $10 \%$ increase in profit. The owner said Branding activities took the role of the case, including the visual identity of the logo, in accordance with the American Marketing Association (AMA) statement in Phillip Kotler's 2002 book entitled "Principles of Marketing". The Het Huisje cafe logo that is not yet strongly illustrates the concept of its business. Visual Audit Results from pre-research Designs Audit, Het Huisje cafe logos do not meet the criteria of memorable and scalable, on a very small scale the logo is hard to read clearly. The application of cafe logos to every Het Huisje cafe medium does not meet the consistent criteria.

\section{THEORETICAL REVIEW}

\section{Design Audit}

A design audit objectively assesses the use of design in an entity. How the design audit is used by an entity and how effectively the design communicates and supports the overall objective. The design audit reveals whether or not there is a consistency between design in the way an entity communicates its vision and values. Design audits can reveal the level of knowledge and understanding of the entity about design as a valuable asset: one that can be used for advanced strategic business purposes (Best, 2006: 44).

\section{Logo}

The identity of a company is a reflection of the vision, mission of a company that is visualized in the company logo. Logo is a real thing as a reflection of things that are non-visual of a company, such as behavioral culture, attitude, personality, as outlined in the form of visual (Soewardikoen, 2007:7). 


\section{RESULT AND DISCUSSION}

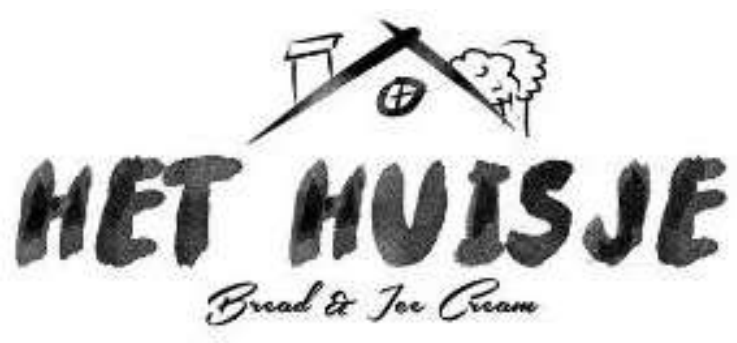

Figure 3.1 Het Huisje Café Logo

(Source: Het Huisje's Private Documentation)

Based on the results of the Design Audit obtained the logo of Het Huisje Cafe still does not meet some criteria of a logo, including the logo is still less legible, the logo is still less simple, and has not described the type of business, product. Therefore, it is necessary to redesign the logo of Het Huisje Cafe by considering the criteria of the logo above, but it must also be able to describe the Dutch-style visual identity in the era of 20 s.

\begin{tabular}{|l|c|}
\hline Logo theory & Logo Het Huisje \\
\hline & \\
\hline $\begin{array}{l}\text { Original \& } \\
\text { Destinctive }\end{array}$ & $\mathbf{X}$ \\
\hline Legible & $\mathbf{X}$ \\
\hline Simple & $\mathbf{X}$ \\
\hline Memorable & $\mathbf{X}$ \\
\hline $\begin{array}{l}\text { Easily } \\
\text { associated } \\
\text { with the } \\
\text { company }\end{array}$ & $\mathbf{X}$ \\
\hline $\begin{array}{l}\text { Easily } \\
\text { adaptable for } \\
\text { all graphic } \\
\text { media }\end{array}$ & $\mathbf{V}$ \\
\hline
\end{tabular}

\begin{tabular}{|l|l|}
\hline \multicolumn{2}{|c|}{ Design Elements } \\
\hline Ilustrasi & Brushed style image \\
\hline Warna & Black \\
\hline Tipografi & $\begin{array}{l}\text { Fantasy font, brushed } \\
\text { style typeface with } \\
\text { water color texture }\end{array}$ \\
\hline Layout & $\begin{array}{l}\text { Center Balanced, } \\
\text { horizontal }\end{array}$ \\
\hline Tagline & Bread and Ice Cream \\
\hline
\end{tabular}

Tabel 3.1 Matriks Analisis Logo

"Investigate the current uses, styles, formats and colours your logo" (Best, 2006:45). Based on the results of the Visual Audit analysis obtained, the logo of the Het Huisje cafe still does not meet some criteria of a good logo: Het Huisje cafe logo will not be easy to remember, as evidenced by too many similar logos on Google image search. Quite timeless with styling "water color brushed" but not depicting 1920s (Art Deco). Logo is less readable in small size because there are many thin lines on the graphics. Het Huisje cafe logo does not describe the type of business, product, or company is also philosophy.Logo easily applied to various media.Logo still less simple, still seen divided into three main parts.

By line is too small and uses typeface Script type so it's hard to read. Kerning typeface is not good. The typography using common typeface that can found on internet. Therefore, the Het Huisje cafe logo needs to be redesigned by considering from the above criteria, but it should also be able to describe the Dutch-style visual identity in the era of 1920s. 
Based on an interview with Owner cafe Het Huisje, this cafe started from the desire to create a growing business and take advantage of great opportunities. It also wants to introduce the culture, history, and culinary of the European continent, especially the Netherlands. The reason why given the name of the house in Dutch, because the owner wants to create a cafe that the atmosphere is comfortable and warm like being at home. The market target of Het Huisje cafe is from young to adults up to 15 years old to 45 years old. Currently Het Huisje cafe is the only cafe in Depok that offers the concept of vintage of the Netherlands and the taste of continental Western Europe. In addition, also began a lot of media that knows the existence of Het Huisje cafe to invite participate in major culinary events in Jakarta and Depok. In 2017 they have been working with an online motorcycle taxi company to facilitate consumers in order.

Brand image is very important to support business activities to achieve its goals, Het Huisje cafe want to make changes to its logo in order to build the appropriate image. They want consumers to also know about the concept of vintage with the Dutch style of 1920 which is applied by Het Huisje cafe. In addition also want to inform that this cafe also provides information about science, culture, and history of the continent of Western Europe.

Based on the results of interviews to consumers who come to Het Huisje cafe, most of them are school children and college students who are studying in the city of Depok. Gustim (24 years old), a student at the University of Indonesia, he knows Het
Huisje cafe from friends on campus, coincidence the owner of this cafe is also a campus with Gustim. In one month Gustim usually come 4 to 6 times to the Het Huisje cafe, usually done there chatting with college friends or just come to eat it. According to Gustim, the facilities offered at Het Huisje cafe is also good from Wifi connection, cleanliness, and comfort of the place. The reason to choose Het Huisje cafe because of its location close to the residence and many campus friends who often gather at this cafe. In addition Het Huisje cafe has an open rooftop, many consumers who come prefers the place, because the air is fresh and the atmosphere that makes it comfortable to linger. The most popular menu in this cafe is a milk shake with many tasty variants with the price offered very affordable by teenagers in Depok. According to Gustim still many shortcomings of this cafe, such as lack of branding to attract more consumers, as well as variations in menu innovation offered to consumers.

\section{Analysis of Results of Questionnaire Data Review}

Based on the results of questionnaire data analysis as much as 55 respondents. Men as many as 18 respondents and women as many as 36 respondents with age at most 27 to 35 years. 50 respondents more often come and hang out at the cafe. The most sought after is the cafe atmosphere as much as 36 respondents.

From the side of branding like the logo of a cafe that they first see is the icon or form of the cafe logo that became the hallmark or differentiator. Cafe logo according to 30 respondents should be easy to remember 
and also according to 50 respondents cafe logo should be able to describe the concept applied from a cafe. Then for the concept and visual style as much as 48 respondents liked the vintage style and know what kind of vintage style. To ensure the questionnaire survey data were given 3 choices of visual styles such as Mondrian style, vintage, and modern vintage as many as 34 respondents chose vintage style. Vintage style suitable for all ages as 28 respondents and 31 respondents said the color of vintage style interesting. And of all the results of the questionnaire as many as 29 respondents said that the Het Huisje cafe logo still does not describe the Dutch-style cafe.

\section{CONCEPT AND RESULTS OF DESIGNS}

\section{Design Audit Recommendation:}

\section{Message Concepts}

The results of logo design analysis in the above design audit, concept message obtained by saying that Het Huisje cafe is a "little Holland" nuanced 1920s era in Depok. Examples that can be applied eg tagline like "Holland in Depok" or "The Dutch Hut" or byline like "old \& new-style Dutch dish".

\section{Creative Concepts}

The results of Visual Audit recommendations produced is, on the design of Het Huisje cafe logo takes the form of icons as "logogram". In accordance with het huisje which means small hut, icon vectors can be taken from traditional Dutch houses like those found in Volledam. This can strengthen the image of the Dutch-style cafe 1920s and where on the window there is a vertical and horizontal line formation as in Piet Modrian's work. Logotype cafe Het Huisje uses sans serif font type on good readability principle. Modifications can be done for example on the stem or font rod by combining combining the shape of grain seeds on the bottom and top of the stem. The addition of wheat seeds can add an impression of the taste of continental Western Europe. Vintage styles can be applied to icon shapes, colors like orange and chocolate that symbolize comfort as well as happiness, and frames (if needed).

\section{CONCLUSION / SUMMARY}

Recommendation is the final result of Design Audit, made to solve existing problems at cafe Het Huisje, used as input process of redesigning visual identity that can communicate entity can be applied with systematic and structured on supporting media of business requirement. Recommendations This visual identity was created to build Het Huisje cafe brand image in Depok society as a Dutch-style cafe in 1920s. 


\section{REFERENCES}

[1] Arikunto, Suharsimi. Prosedur Penelitian Suatu Pendakatan Praktik. Jakarta: Rineka Cipta. 2006.

[2] Bernal, German Castro. Visual Marketing, Institución Universitaria Esumer Department Facultad de Estudios Internacionales Presentation, Bogotá, April 2016.

[3] Best, Kathryn. Design Management. Lausanne, Switzerland: AVA Academia, 2006. Print.

[4] Borja de Mozota, Brigitte. Design Management. New York, NY: Allworth Press, 2003. Print.

[5] E. Bürdek Basel, Bernhard. Design: The History, Theory and Practice of Product Design. Birkhäuser, 2006. Print.

[6] Kotler, P. \& Keller, K.L. Marketing Management 14E. Prentice Hall, Boston, 2012. Print.

[7] Moultrie, James, P. John Clarkson, and David Probert. "Development Of A Design audit Tool For Smes". Journal of Product Innovation Management 24.4 (2007): 335-368. Web.

[8] Soewardikoen, D. Widiatmoko. 2013. Metodologi Penelitian Visual. Bandung. PT Dinamika Komunika.

[9] Sugiyono. Metodologi Penelitian Kuantitatif Kualitatif Dan $R$ \& D (Cetakan ke14). Bandung: Alfabeta. 2011.

[10] "DM5562: Strategic Design Management \& Research | Brunel University". Readinglists.brunel.ac.uk. N.p., 2016. Web. 19 May 2016 